\title{
Germ cell cluster formation and ovariole structure in Puto albicans and Crypticerya morrilli (Hemiptera: Coccinea). Phylogenetic implications
}

\author{
TERESA SZKLARZEWICZ, AnNa MICHALIK, ANNA CZAJA and Sylwia SZYDŁOWSKA
}

Department of Systematic Zoology and Zoogeography, Institute of Zoology, Jagiellonian University, R. Ingardena 6, 30-060 Kraków, Poland, e-mail: teresa.szklarzewicz@uj.edu.pl

\begin{abstract}
Key words. Coccinea, Putoidae, Monophlebidae, Puto albicans, Crypticerya morrilli, scale insects, ovaries, clusters of germ cells, telotrophic ovariole, oogenesis, endosymbiotic microorganisms, phylogeny
\end{abstract}

\begin{abstract}
The organization and development of ovaries in representatives of two families (Putoidae and Monophlebidae) of scale insects are described. Developing ovaries of Puto albicans McKenzie, 1967 and Crypticerya morrilli (Cockerell, 1914) consist of numerous clusters of cystocytes that are arranged in the form of rosettes. At the end of the last nymphal instar these clusters start to protrude from the interior of the ovary into the body cavity and the ovarioles begin to be formed. The ovary of a young female is composed of about 200 spherical telotrophic ovarioles devoid of terminal filaments. The ovarioles of C. morrilli contain 8 germ cells ( 7 trophocytes and a single oocyte). From 25 to 45 germ cells (23-43 trophocytes and 2 or 3 oocytes) occur in the ovarioles of $P$. albicans. An ovariole of an adult female is subdivided into a trophic chamber (tropharium), vitellarium and ovariolar stalk (pedicel). At each stage of development, the ovaries are accompanied by large cells (termed bacteriocytes) that contain endosymbiotic microorganisms. The organization of the ovary in P. albicans is more similar to that in archaeococcoid scale insects than in neococcoid taxa. In contrast, the number of germ cells per ovariole in $C$. morrilli is not typical of other archaeococcoids, but resembles the derived condition seen in other iceryine taxa. The classification and phylogeny of scale insects are discussed in the light of these results.
\end{abstract}

\section{INTRODUCTION}

Scale insects are plant pests with a world-wide distribution. They are characterized by unusual sexual dimorphism. Adult females are larviform, apterous and usually immobile. Males have one pair of wings and nonfunctional mouthparts. The monophyletic origin of scale insects, which is based on the numerous synapomorphies in this group, is widely accepted by entomologists (for further details see e.g. Koteja, 1974, 1996; Miller \& Kosztarab, 1979; Gullan \& Cook, 2007). Scale insects are classified into two informal groups, the primitive archaeococcoids and advanced neococcoids (Borchsenius, 1956). The monophyly of neococcoids is well documented and recently supported by molecular analyses (Cook et al., 2002). The neoccoid scale insects are classified into 17 well defined families, including Pseudococcidae, Kermesidae, Eriococcidae, Coccidae, Asterolecaniidae, Diaspididae and several smaller families (Gullan \& Cook, 2007). In contrast to the neococcoids, the phylogeny and classification of archaeococcoids is still being debated (Koteja, 1974, 1996; Gullan \& Sjaarda, 2001; Cook et al., 2002; Gullan \& Cook, 2007). Since this group is characterized by plesiomorphic characters only, its monophyly is uncertain (Koteja, 1996; Cook et al., 2002). Morrison (1928) distinguished two families of archaeococcoids, the Ortheziidae and Margarodidae. The latter contained five subfamilies: Coelostomidiinae, Margarodinae, Monophlebinae, Steingeliinae and Xylococcinae. Koteja (1974) on the basis of mouthpart morphology elevated these subfamilies and two tribes sensu Morrison (i.e. Kuwanini and Matsucoc- cini) to family rank. Additionally, Koteja (1974) included the small family Phenacoleachiidae in the archaeococcoid group. It should be emphasized that recent morphological (Gullan \& Sjaarda, 2001; Foldi, 2005; Szklarzewicz et al., 2005; Hodgson \& Foldi, 2006) and molecular data (Cook et al., 2002) confirm Koteja's classification. For several years some entomologists placed the family Putoidae, containing the single genus Puto McKenzie, with the archaeococcoids (e.g. Foldi, 2005; Hodgson \& Foldi, 2006; Gullan \& Cook, 2007; Kondo et al., 2008). It should be noted that the taxonomic position of the genus Puto is still under discussion. For many years, due to similarity in female morphology, Puto was regarded as a member of the advanced family Pseudococcidae (e.g. Koteja, 1974; Miller \& Miller, 1993). Beardsley (1969), based on the morphological characters of males, concluded that Puto is a primitive neococcoid and should be placed in its own family, the Putoidae. Koteja (1996; pers. commun.) considered Puto as the ancestor of all neococcoids on account of its primitive characters. Cook and co-workers (2002), on the basis of molecular analysis, suggested that Puto is not a neococcoid. Thus, the controversy surrounding this genus warrants further studies directed at clarifying its systematic position.

The ovaries of scale insects were extensively studied over the last three decades (Książkiewicz, 1980; Szklarzewicz \& Biliński, 1995; Szklarzewicz, 1997, 1998a, b, c; Koteja et al., 2003; Szklarzewicz et al., 2005; Niżnik \& Szklarzewicz, 2007). The ovaries consist of short telotrophic ovarioles devoid of terminal filaments. Each ovariole is composed of a trophic chamber (tropharium), 
vitellarium and ovariolar stalk (pedicel). The vitellarium usually contains a single oocyte. The ovarioles of scale insects, on account of their atypical organization (lack of a terminal filament, a single oocyte in the vitellarium, a small number of trophocytes in the tropharium), were formerly regarded as polytrophic or dieroistic (Jura, 1958; Węglarska, 1961; Magakyan et al., 1975). Szklarzewicz and co-workers in a series of papers (Szklarzewicz \& Biliński, 1995; Szklarzewicz, 1997, 1998a, b, c; Koteja et al., 2003; Szklarzewicz et al., 2005; Niżnik \& Szklarzewicz, 2007) have shown that the ovarioles of archaeococcoid scale insects markedly differ in organization and functioning from those of neococcoid scale insects. First, the total number of germ cells (trophocytes + oocytes) constituting the ovariole in archaeococcoids is much larger than in neococcoids. Second, tropharia of archaeococcoids (except for members of the family Monophlebidae) contain trophocytes and early previtellogenic oocytes (termed arrested oocytes), whereas in neococcoids the tropharia contain only trophocytes (except for representatives of the family Kermesidae and some Eriococcidae). The arrested oocytes in archaeococcoid scale insects are capable of further development, while those in kermesids and eriococcids do not develop, but degenerate, even those in tropharia. Thus, the ovaries of archaeococcoids appear more similar in organization and functioning to the ovaries of aphids (for further details see Büning, 1985; Szklarzewicz et al., 2000) than to those of neococcoids. Apart from the above features that are atypical of insects, the ovaries of scale insects so far investigated are characterized by a unique mechanism of ovariole formation (Węglarska,1961; Szklarzewicz, 1997; 1998a, b, c; Niżnik \& Szklarzewicz, 2007). Although in most insects the ovarioles arise inside the ovary, in scale insects, the ovariole anlagen protrude from the interior of the ovary into the body cavity. However, there is no detailed description of this process in the literature.

Since comparative studies on the organization of the ovaries in scale insects (for further details see Szklarzewicz, 1998a; Koteja et al., 2003) and several other groups of insects (e.g. heteropterans, mecopterans, adephagan beetles, dipterans, neuropterans) have shown that this character is very useful for phylogenetic studies (for fur-

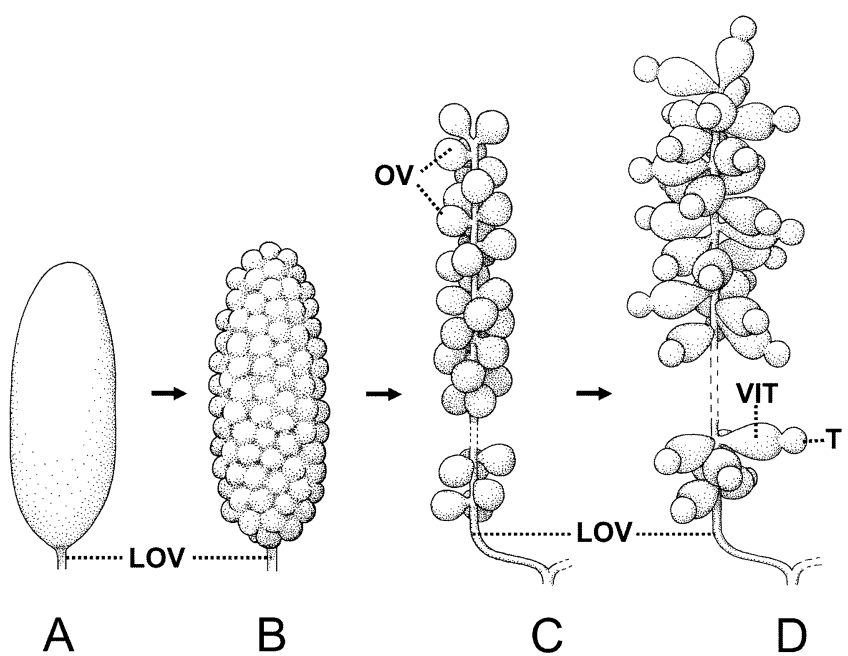

Fig. 1. Schematic representation of the development of an ovary of a scale insect. A - The spindle-shaped ovary in a last nymphal instar. B - The ovary at the end of the last nymphal instar. Clusters of cystocytes start to protrude from the interior of the ovary into the body cavity. C - The ovary of a young female. Ovarioles (OV) are radially arranged around the lateral oviduct (LOV). D - The ovary of an adult female. Ovarioles consist of tropharia (T) and vitellaria (VIT).

ther details see e.g. Biliński et al., 1998; Jaglarz, 1998; Kubrakiewicz et al., 1998a, b; Simiczyjew et al., 1998), the aim of this work is to verify the taxonomic placement of Puto on the basis of the organization of its ovaries.

\section{MATERIAL AND METHODS}

The ovaries of Puto albicans and Crypticerya morrilli were studied using ultrastructural and histological methods.

McKenzie (1967) in his description of $P$. albicans stated that adult females do not produce ovisacs. The adult female of $C$. morrilli, which lays its eggs in a marsupium, was re-described by Unruh (2008).

Specimens of P. albicans were collected from twigs of Arctostaphylos viscida near Placerville (El Dorado County, California, USA) in May and specimens of C. morrilli (Cockerell, 1914) from twigs of Acacia greggii in Red Rock State Park (Yavapai County, Arizona, USA), also in May. The entire abdomens of individuals of each species were fixed in $2.5 \%$ glutaraldehyde in $0.1 \mathrm{M}$ phosphate buffer ( $\mathrm{pH}$ 7.4) for 3 months. The

Figs 2-10. 2 - P. albicans (Putoidae). Fragment of the ovary in a last nymphal instar. The ovary is filled with clusters of cystocytes (CC). Arrows indicate somatic cells surrounding the clusters. Methylene blue, scale bar $=20 \mu \mathrm{m} .3-P$. albicans (Putoidae). Fragment of a cystocyte (CC) in the ovary of the last nymphal instar. The cystocyte cytoplasm is filled with numerous endosymbiotic bacteria (B). Note the synaptonemal complex (arrow) in the cystocyte nucleus (CN). TEM, scale bar $=2 \mu \mathrm{m} .4,5-C$. morrilli (Monophlebidae). Fragment of the ovary (longitudinal section) at the end of the last nymphal instar. Clusters of cystocytes (encircled) start to protrude from the interior of the ovary into the body cavity. Note the long ovariolar stalks $(\mathrm{P})$ and deeply folded wall of the lateral oviduct (arrow). Asterisk - lumen of lateral oviduct. Methylene blue, scale bar $=20 \mu \mathrm{m}$. $6-P$. albicans (Putoidae). Fragment of the ovary (longitudinal section) of a young female. The spherical ovarioles (OV) are arranged in a radial pattern around the lateral oviduct (arrow). Methylene blue, scale bar $=20 \mu \mathrm{m} .7-P$. albicans (Putoidae). A longitudinal section of an ovariole of an adult female. The germ cells are differentiated into trophocytes (TC) and oocytes (OC). The ovary is accompanied by bacteriocytes (BC). LOV - lateral oviduct; P - ovariolar stalk; TN - trophocyte nucleus. Methylene blue, scale bar $=20 \mu \mathrm{m}$. 8,9 $-P$. albicans (Putoidae). An ovariole of an adult female. 8 - longitudinal section; 9 - cross section. In the centre of the tropharium is a trophic core (TR). Note the endosymbiotic bacteria (encircled) in the cytoplasm of the germ cells. Black arrow - nutritive cord; white arrow - oocyte nucleus; $\mathrm{BC}$ - bacteriocyte; F - follicular epithelium; OC - oocyte; TC - trophocyte; TN - trophocyte nucleus. Methylene blue, scale bar $=20 \mu \mathrm{m} .10-C$. morrilli (Monophlebidae). An ovariole of an adult female (longitudinal section). Note the large, lobate nuclei (TN) of trophocytes (TC). White arrow - flattened cells of the inner epithelial sheath; black arrow - nutritive cord; F - follicular epithelium; OC - oocyte; ON - oocyte nucleus; TR - trophic core. Methylene blue, scale bar $=20 \mu \mathrm{m}$. 


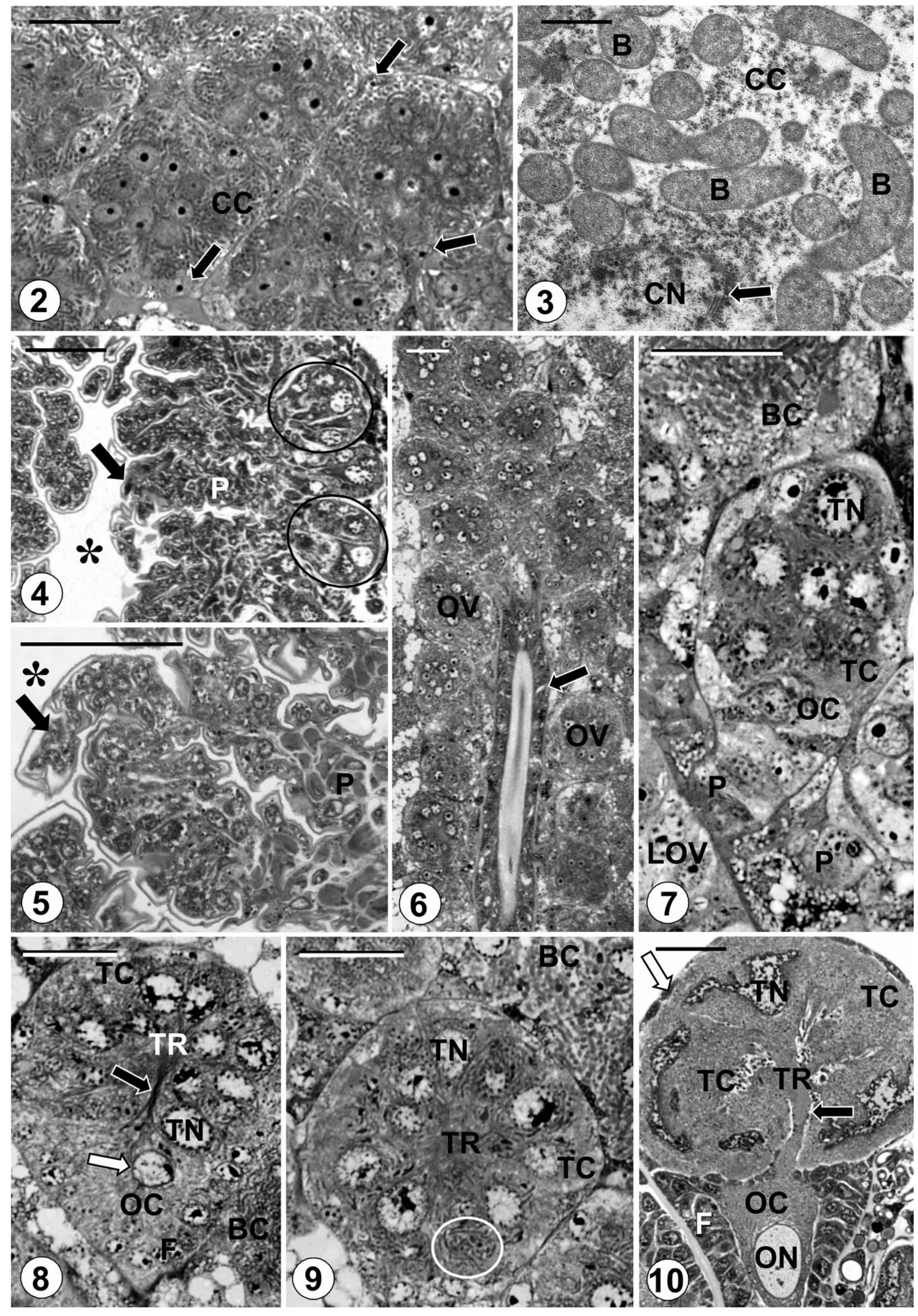


material was next rinsed with a mixture of the buffer and sucrose $(5.8 \mathrm{~g} / 100 \mathrm{ml})$ and postfixed for $1.5 \mathrm{~h}$ in $1 \%$ osmium tetroxide. After dehydration in a series of ethanol and acetone, material was embedded in the epoxy resin Epon 812 (Fullam, Latham, N.Y., USA). Semithin sections were stained with $1 \%$ methylene blue in $1 \%$ borax and photographed under a Jenalumar microscope. Ultrathin sections were contrasted with uranyl acetate and lead citrate and examined under a JEM $100 \times$ electron microscope at $80 \mathrm{kV}$.

\section{RESULTS}

During the last nymphal instar the spindle-shaped ovaries (Fig. 1A) of Puto albicans and Crypticerya morrilli are filled with numerous clusters of undifferentiated germ cells termed cystocytes (Fig. 2). The cystocytes are integrated into rosettes (Fig. 2). Each cluster is surrounded by a single layer of flattened somatic cells (Fig. 2). Groups of somatic cells also occur among clusters (not shown). Analysis of serial semi-thin sections has shown that each cluster of $C$. morrilli consists of 8 cystocytes. The clusters in $P$. albicans consist of a greater number, even as many as 40 cystocytes. All of the cystocytes in a cluster are interconnected by intercellular bridges (not shown). Cystocytes are all morphologically similar. They are coneshaped and have large spherical nuclei with a single nucleolus (Fig. 2). Synaptonemal complexes occur in the nuclei of all cystocytes (Fig. 3). In P. albicans, the cystocyte cytoplasm contains numerous endosymbiotic bacteria (Figs 2, 3). These endosymbionts are elongate and measure about $10 \mu \mathrm{m}$ in length and $1 \mu \mathrm{m}$ in diameter.

Long ovariolar stalks (pedicles) are formed at the proximal pole of each spherical cluster at the end of the last nymphal instar (Fig. 4). Simultaneously, somatic cells start to form the distal part of the lateral oviduct (Figs 4, 5). At the beginning of this process the wall of the lateral oviduct is deeply folded (Figs 4, 5). At the stage when the formation of ovariolar stalks is completed, the clusters of cystocytes start to protrude from the ovary into the body cavity (Figs 1B, 4). As this process progresses, the folds of the lateral oviduct wall stretch and the lateral oviduct takes on the form of an elongated tube (Fig. 6). Consequently the ovary of a young female (shortly after it emerges as an adult) is composed of numerous (about 200) spherical ovarioles, which are radially arranged around the lateral oviduct (Figs 1C, 6). The ovarioles are devoid of terminal filaments (Figs 1C, 6). As before, all of the cystocytes in a cluster are morphologically similar. In adult females, the ovarioles become elongated (Fig. 7). Simultaneously, the cystocytes differentiate into trophocytes and oocytes (Fig. 7). Analysis of serial sections of 10 ovarioles revealed a constant number of 7 trophocytes and a single oocyte in the ovarioles of $C$. morrilli. In those of $P$. albicans there are from 25 to 45 germ cells (23-43 trophocytes and 2 or 3 oocytes). In both these species the trophocytes occupy the distal part of an ovariole, whereas the oocyte or oocytes are localized in the proximal region (Fig. 7). In $P$. albicans, the oocyte closest to the lateral oviduct develops first (Figs 7, 8). Subsequently, the distal part of the ovariole transforms into a tropharium (trophic chamber) and proximal part into the vitellarium (Figs 1D, 8). The latter contains a single oocyte (Fig. 8). In P. albicans, the remaining 1 or 2 oocytes (termed arrested oocytes) are localized in the proximal part of the tropharium (not shown). The somatic cells surrounding the ovariole differentiate into the flattened cells of the inner epithelial sheath and the follicular cells. The latter form a single-layered epithelium around the developing oocyte (Fig. 10). The inner epithelial sheath encompasses the tropharium (Fig. 10). The central area of the tropharium, termed the trophic core, is connected with both the trophocytes and oocytes (Figs 8-10). Trophocytes are joined to the trophic core by means of broad processes (Figs 8-10), whereas oocytes are connected via nutritive cords (Figs 8, 10). In the ovarioles of older females the trophocyte nuclei become large and lobate (Fig. 10). The trophocyte cytoplasm is filled mainly with ribosomes (not shown). Numerous elongate bacteria are present in the trophocytes and oocytes in $P$. albicans (Figs 8, 9).

Ovarioles develop synchronously in $P$. albicans and $C$. morrilli, i.e. they start to grow out of the spindle-shaped ovary into the body cavity at the same time (Figs 1B, 4). As a consequence, all the ovarioles in the ovary of an adult female are at the same developmental stage (Fig. 1D).

There are giant cells termed bacteriocytes associated with the ovaries in both of the species studied (Figs 7-9). The cytoplasm of these cells is tightly packed with endosymbiotic microorganisms (Figs 7-9).

\section{DISCUSSION}

Results presented in this paper indicate that the ovaries of Puto albicans and Crypticerya morrilli develop in the same manner, i.e. the ovarioles protrude from the interior of the ovary into the body cavity. A comparison of these results with previous observations on the ovaries of archaeococcoids and neococcoids (Węglarska, 1961; Szklarzewicz, 1997, 1998a, b, c; Niżnik \& Szklarzewicz, 2007) indicates that the ovary develops similarly in all scale insects. Thus, this character may be regarded as a synapomorphy for scale insects. Since the development of ovarioles in scale insects starts with the formation of ovariolar stalks, it may be speculated that, as in other pterygote insects (for further details see Büning, 1994), the somatic cells of the ovaries play a crucial role in their development.

As a rule, ovarioles in scale insects develop asynchronously (Węglarska, 1961; Bielenin, 1962; Szklarzewicz \& Biliński, 1995; Szklarzewicz, 1997, 1998a, b, c; Szklarzewicz et al., 2005; Niżnik \& Szklarzewicz, 2007). Consequently, in the ovary of an adult female the neighbouring ovarioles are at different stages of oogenesis. Weglarska (1961) observed that in the oystershell scale, Quadraspidiotus ostreaeformis (Curtis) (Diaspididae), the ovarioles located in the distal region of an ovary develop earlier than those located in the proximal region. According to Węglarska (1961), young undifferentiated ovariole anlagen occur among well-developed ovarioles in the distal region. This study indicates that unlike the 
situation in most scale insects, the ovarioles in $P$. albicans and $C$. morrilli develop synchronously. Koteja et al. (2003) postulated that synchronous development of ovarioles is associated with a shortening of the oviposition period.

The observations reported here indicate that the ovaries of both of the species investigated are accompanied by bacteriocytes (formerly termed mycetocytes), which contain endosymbiotic microorganisms. In P. albicans, endosymbiotic bacteria were observed both in the bacteriocytes and cytoplasm of germ cells. It is generally accepted that the presence of endosymbiotic microorganisms (bacteria or yeasts) in an insect's body is connected with it feeding on a diet deficient in some essential nutrients (for further details see Douglas, 1989; Baumann, 2005). In scale insects, as in other plant sap-sucking hemipterans, endosymbiotic microorganisms are responsible for the synthesis of essential amino acids, which are absent in the phloem sap. The endosymbionts are transovariallly (vertically) transmitted from mother to offspring (Buchner, 1965; Szklarzewicz \& Moskal, 2001; Szklarzewicz et al., 2006; Michalik et al., 2009). Variable modes of infection of germ cells by microorganisms have developed during the co-evolution of scale insects and their endosymbionts. The latter may invade young germ cells (oogonia or cystocytes) or older oocytes (vitellogenic or choriogenic). The latter process is more common among scale insects (Buchner, 1965; Szklarzewicz et al., 2006; Niżnik \& Szklarzewicz, 2007). The occurrence of an enormous number of bacteria in all of the germ cells (cystocytes, trophocytes, oocytes) in P. albicans suggests that in this species the infection of germ cells occurs before their differentiation into oocytes and trophocytes.

\section{Phylogenetic conclusions}

The results indicate that the ovarioles of $P$. albicans are composed of numerous germ cells (trophocytes + oocytes). The number of germ cells in the ovarioles analyzed varies between 25 and 44. Thus, it is similar or even larger than the number in ovarioles of other archaeococcoid families, such as the Ortheziidae (15-58 germ cells), Margarodidae s. str. (12-19 germ cells), Steingeliidae (21-41 germ cells) and Monophlebidae (8 germ cells) (Szklarzewicz \& Biliński, 1995; Szklarzewicz, 1997, 1998c; Koteja et al., 2003; Szklarzewicz et al., 2005; Niżnik \& Szklarzewicz, 2007). The neococcoid families are characterized by a smaller number of germ cells per ovariole. Among the neococcoid scale insects, the largest number of germ cells occurs in ovarioles of the Kermesidae (i.e, 8-20) (Szklarzewicz, 1998b). In the Pseudococcidae and some species of Eriococcidae and Coccidae, the number of germ cells is 8 or slightly more than 8 (e.g. 10 in some coccids) (Szklarzewicz, 1998b; Witek, 2002). The smallest number of germ cells (i.e. 4) is reported for the Diaspididae, Cryptococcidae and some species of Coccidae and Eriococcidae (Węglarska, 1961; Bielenin, 1962; Książkiewicz, 1980; Szklarzewicz, 1998b).

The considerations mentioned above clearly indicate that the ovarioles of $P$. albicans are more similar to those of archaeococcoids than neoccoccoids. This in turn, strongly supports the conclusion based on molecular data that the genus Puto should be placed among the archaeococcoids. This assumption also corresponds well with the results of studies on chromosome behaviour in scale insects. For over sixty years it has been known that the genus Puto is characterized by a primitive chromosome system, termed a "XX-XO chromosome system" (Hughes-Scharader, 1944). Besides Puto, this sex determining system is found in aphids (Blackman, 1985) and most archaeococcoids (Hughes-Schrader, 1948). In neococcoids and a few archaeococcoids, there are several other systems (Miller \& Kosztarab, 1979). It is noteworthy that Hughes-Schrader (1948) and Brown and Cleveland (1968), on the basis of chromosome behaviour, suggested that Puto is more distantly related to pseudococcids than usually supposed.

The family Monophlebidae, which includes C. morrilli, is regarded as one of the most primitive archaeococcoid families among scale insects (Koteja, 1974). The monophyly of this family was established on the basis of characters of female morphology (Koteja, 1974; Gullan \& Sjaarda, 2001). The present study of the ovaries of $C$. morrilli (from the tribe Iceryini) and earlier examinations of ovaries of other members of the family Monophlebidae - Icerya purchasi Maskell (from the tribe Iceryini) and Palaeococcus fuscipennis (Burmeister) (from the tribe Monophlebini) (Hughes-Schrader, 1927; Szklarzewicz et al., 2005; Niżnik \& Szklarzewicz, 2007), revealed that their ovarioles always contain 8 germ cells ( 7 trophocytes + single oocyte). Therefore, it is likely that the occurrence of 8 germ cells per ovariole is a characteristic feature of all monophlebids. Thus, this character gives additional support for the monophyly of the family Monophlebidae. Szklarzewicz et al. (2005) observed that ovary organization in monophlebids seems to be more similar to that in the neococcoid family Pseudococcidae than to that in other archaeococcoid families, such as Ortheziidae, Margarodidae s. str. and Steingeliidae. Assuming that the large number of germ cells per ovariole represents the ancestral condition within scale insects (Szklarzewicz, 1998 a; Koteja et al., 2003), it may be speculated that the same number of germ cells in ovarioles in monophlebids and pseudococcids may be the result of homoplasy, i.e. this character evolved independently in both families.

Previous (Szklarzewicz, 1998c; Koteja et al., 2003; Szklarzewicz et al., 2005) and the present study on the ovaries of representatives of families Margarodidae s. str., Steingeliidae and Monophlebidae (i.e. Margarodidae sensu Morrison) have revealed that they are characterized by distinct structure. They may contain large and variable numbers of germ cells per ovariole (Margarodidae s. str., Steingeliidae) or small and stable numbers (Monophlebidae). Several oocytes may develop in their vitellaria (Margarodidae s. str., Steingeliidae) or just a single oocyte (Monophlebidae). These observations strongly support the division of the Margarodidae sensu Morrison into several small families as suggested by Koteja (1974).

ACKNOWLEDGEMENTS. We are greatly indebted to P. Gullan, T. Kondo and C. Unruh (all from the University of Califor- 
nia, Davis) for providing material and to A. Jankowska, B. Szymańska and O. Woźnicka for their skilled technical assistance. This study was supported by Research Grant BW/IZ/2008.

\section{REFERENCES}

BAUMANN P. 2005: Biology of bacteriocyte-associated endosymbionts of plant sap-sucking insects. Annu. Rev. Microbiol. 59: 155-189.

BeARDSley J.W. 1969: A new fossil scale insect (Homoptera: Coccoidea) from Canadian amber. Psyche 76: 270-279.

BIELENIN I. 1962: Anatomical and histochemical investigations on the genus Lecanium Burm. Part. I. Female reproductive organs of Lecanium pomeranicum Kaw. (Homoptera, Coccoidea). Acta Biol. Crac. (Zool.) 5: 9-25.

BiLiński S.M., BünIng J. \& Simiczyjew B. 1998: The ovaries of Mecoptera: basic similarities and one exception to the rule. Folia Histochem. Cytobiol. 36: 189-196.

BlaCKMAN R.L. 1985: Aphid cytology and genetics. In Szelęgiewicz H. (ed.): Evolution and Biosystematics of Aphids. Proceedings of the International Symposium at Jablonna. Ossolineum, Wrocław, pp. 171-237.

Borchsenius N. 1956: The question of the course of evolution of Coccoidea (Insecta, Homoptera) . Zool. Zh. 35: 546-553 [in Russian].

Brown S.W. \& Cleveland C. 1968: Meiosis in the male of Puto albicans (Coccoidea, Homoptera). Chromosoma 24: 210-232.

Buchner P. 1965: Endosymbiosis of Animals with Plant Microorganisms. Interscience, New York, 909 pp.

BüNING J. 1985: Morphology, ultrastructure and germ cell cluster formation in ovarioles of aphids. J. Morphol. 86: 209-221.

BüNING J. 1994: The ovary of the Ectognatha, the Insecta s. str. In Büning J. (ed.): The Insect Ovary: Ultrastructure, Previtellogenic Growth and Evolution. Chapman and Hall, London, pp. 32-400.

Cook L.G., Gullan P.J. \& Trueman H.E. 2002: A preliminary phylogeny of the scale insects (Hemiptera: Sternorrhyncha: Coccoidea) based on nuclear small-subunit ribosomal DNA. Mol. Phyl. Evol. 25: 43-52.

Douglas A.E. 1989: Mycetocyte symbiosis in insects. Biol. Rev. 64: 409-434.

FOLDI I. 2005: Ground pearls: a generic revision of the Margarodidae sensu stricto (Hemiptera: Sternorrhyncha: Coccoidea). Ann. Soc. Entomol. Fr. (N.S.) 41: 81-125.

Gullan P.J. \& CoOK L.G. 2007: Phylogeny and higher classification of the scale insects (Hemiptera: Sternorrhyncha: Coccoidea). Zootaxa 1668: 413-425.

Gullan P.J. \& SJAARDA W. 2001: Trans-Tasman Platycoelostoma Morrison (Hemiptera: Coccoidea: Margarodidae) on endemic Cupressaceae, and the phylogenetic history of margarodids. Syst. Entomol. 26: 257-278.

Hodgson C. \& Foldi I. 2006: A review of the Margarodidae sensu Morrison (Hemiptera: Coccoidea) and some related taxa based on the morphology of adult males. Zootaxa 1263: $1-250$.

Hughes-Schrader S. 1927: Origin and differentiation of the male and female germ cells in the hermaphrodite of Icerya purchasi (Coccidae). Z. Zellforsch. 6: 509-540.

Hughes-Schrader S. 1944: A primitive coccid chromosome cycle in Puto sp. Biol. Bull. 87: 167-176.

Hughes-Schrader S. 1948: Cytology of coccids (Coccoidea, Homoptera). Adv. Genet. 2: 127-203.

JAGLARZ M.K. 1998: The number that counts. Phylogenetic implications of the number of nurse cells in ovarian follicles of Coleoptera, Adephaga. Folia Histochem. Cytobiol 36: $167-178$.

JURA C. 1958: The early developmental stages of ovoviviparous scale insect Quadraspidiotus ostreaeformis (Curt.) (Homoptera, Coccidae, Aspidiotini). Zool. Polon. 9: 17-34.

Kondo T., Gullan P.J. \& Williams D.J. 2008: Coccidology. The study of scale insects (Hemiptera: Sternorrhyncha: Coccoidea). Rev. Corpoica-Cienc. Tec. Agr. 9: 55-61.

Kотела J. 1974: On the phylogeny and classification of the scale insects (Homoptera, Coccinea) (discussion based on the morphology of the mouthparts). Acta Zool. Crac. 14: 267-325.

Koteja J. 1996: Scale insects (Homoptera: Coccinea) a day after. In Schaefer C.W. (ed.): Studies of Hemipteran Phylogeny. Proceedings of Thomas Say Publications in Entomology. Entomological Society of America, Lanham, Maryland, pp. 65-88.

Koteja J., Pyka-Fościak G., Vogelgesang M. \& Szklarzewicz T. 2003: Structure of the ovary in Steingelia (Sternorrhyncha: Coccinea), and its phylogenetic implications. Arthr. Struct. Dev. 32: 247-256.

KSIĄŻKIEWICZ M. 1980: Ultrastructure of the trophic chamber and nutritive cord of Aspidiotus hederae (Homoptera, Coccoidea). Cell Tiss. Res. 213: 149-157.

Kubrakiewicz J., Biliński S.M. \& Mazurkiewicz M. 1998a: Diptera - ovary structure and oogenesis in midges and flies. Folia Histochem. Cytobiol. 36: 197-203.

Kubrakiewicz J., JĘDRZEJowsKa I. \& BiLińsKi S.M. 1998b: Neuropteroidea - different ovary structure in related groups. Folia Histochem. Cytobiol. 36: 179-187.

Magakyan Y.A., Makaryan S.R., Petrossyan A.V., Mktchyan L.P., Abroyan L.O. \& Hakopyan L.A. 1975: The oogenesis of the ararat cochineal (Porphyrophora hamelli Brandt). I. Histomorphological characteristics of the formation of follicular apparatus and the development of oocytes. Cytologia 18: 932-936 [in Russian].

McKenzie H.L. 1967: Mealybugs of California with Taxonomy, Biology, and Control of North American Species (Homoptera: Coccoidea: Pseudococcidae). University of California, Berkeley, 526 pp.

Michalik A., Jankowska W. \& Szklarzewicz T. 2009: Ultrastructure nad transovarial transmission of endosymbiotic microorganisms in Conomelus anceps and Metcalfa pruinosa (Insecta, Hemiptera, Fulgoromorpha). Folia Biol. (Kraków) 57: 131-137.

Miller D.R. \& Kosztarab M. 1979: Recent advances in the study of scale insects. Annu. Rev. Entomol. 24: 147-152.

Miller D.R. \& Miller G.L. 1993: A new species of Puto and preliminary analysis of the phylogenetic position of the Puto group within the Coccoidea (Homoptera: Pseudococcidae). Jeffersoniana 4: 1-35.

Morrison H. 1928: A classification of the higher groups and genera of the coccid family Margarodidae. US Dep. Agr. Wash. Tech. Bull. 52: 1-237.

NiżNIK S. \& SzKLARZEWICZ T. 2007: Structure and development of hermaphroditic gonad in Icerya purchasi (Insecta, Hemiptera, Coccinea: Monophlebidae). Zool. Polon. 52: 71-90.

Simiczyjew B., OgorzaleK A. \& Š Tys P. 1998: Heteropteran ovaries: variations on the theme. Folia Histochem. Cytobiol. 36: $147-156$.

SzkLARZEWICZ T. 1997: Structure and development of the telotrophic ovariole in ensign scale insects (Hemiptera, Coccomorpha: Ortheziidae). Tiss. Cell 29: 31-38.

SzKLARZEWICZ T. 1998a: The ovaries of scale insects (Hemiptera, Coccinea). Morphology and phylogenetic conclusions. Folia Histochem. Cytobiol. 36: 157-165. 
SzKLARZEWICZ T. 1998b: Structure of ovaries of scale insects. I. Pseudococcidae, Kermesidae, Eriococcidae, and Cryptococcidae (Insecta, Hemiptera, Coccinea). Int. J. Insect Morphol. Embryol. 27: 162-172.

SzKLARZEWICZ T. 1998c: Structure of ovaries of scale insects. II. Margarodidae (Insecta, Hemiptera, Coccinea). Int. J. Insect Morphol. Embryol. 27: 319-324.

SzKLARZEWICZ T. \& BilińsKi S.M. 1995: Structure of ovaries in ensign scale insects, the most primitive representatives of Coccomorpha (Insecta, Hemiptera). J. Morphol. 224: 23-29.

SzKLARZEWicz T. \& MosKal A. 2001: Ultrastructure, distribution, and transmission of endosymbionts in the whitefly Aleurochiton aceris Modeer (Insecta, Hemiptera, Aleyrodinea). Protoplasma 218: 45-53.

SzKLARZEWicz T., WNĘK A. \& Biliński S.M. 2000: Structure of ovarioles in Adelges laricis, a representative of the primitive aphid family Adelgidae. Acta Zool. Stockholm 81: 307-313.

SzKLarzewicz T., KęDra K. \& NiżNIK S. 2005: Ultrastructural studies of the ovary of Palaeococcus fuscipennis (Burmaister)
(Insecta, Hemiptera, Coccinea: Monophlebidae). Folia Biol. (Kraków) 53: 45-50.

SzKlarzewicz T., KęDra K. \& NiżNIK S. 2006: Ultrastructure and transovarial transmission of endosymbiotic microorganisms in Palaeococcus fuscipennis (Burmeister) (Insecta, Hemiptera, Coccinea: Monophlebidae). Folia Biol. (Kraków) 54: 70-74.

UnRUH C.M. 2008: A taxonomic review of the Crypticerya species (Hemiptera: Coccoidea: Monophlebidae) of the southwestern United States and Mexico, including description of a species from Baja California. Zootaxa 159: 1-42.

WĘGLARSKA B. 1961: Oogenesis in the ovoviviparous scale insect Quadraspidiotus ostreaeformis Curt. (Homoptera, Coccidae, Aspidiotini). Part I. Morphological and cytological investigations. Zool. Polon. 11: 267-294.

WiteK A. 2002: Ovariole Structure in Eulecanium tiliae and Ceroplastes sp. (Insecta, Hemiptera, Coccinea: Coccidae). MSc Thesis. Department of Systematic Zoology and Zoogeography, Jagiellonian University [in Polish].

Received March 19, 2010; revised and accepted June 17, 2010 